\title{
23 VIOLATION OF THE DOCTRINE OF SEPARATION OF POWERS IMPOSED THROUGH PROPOSED REGULATION OF RELIGION IN SOUTH AFRICA
}

\section{Mary-Anne Plaatjies-Van Huffel ${ }^{1}$}

\section{INTRODUCTION}

This chapter explores the proposed regulation of religion in South Africa, drafted by the Commission for the Promotion and Protection of the Rights of Cultural, Religious and Linguistic Communities (CRL Rights Commission) during the 2016-2017 period. The CRL Rights Commission issued three documents with regard to the regulation of religion, namely the "Preliminary Report of the Hearings on Commercialisation of Religion and Abuse of People's Belief Systems" (Preliminary Report), ${ }^{2}$ the "Report of the Hearings on Commercialisation of Religion and Abuse of People's Belief Systems" (Second Report) ${ }^{3}$ and the "Report of the Hearings on Commercialisation of Religion and Abuse of People's Belief Systems" (Final Report). ${ }^{4}$ The Second Report was published the day after the Preliminary Report on the CRL Rights Commission's website and the Final Report was published on 27 April 2017. The CRL Rights Commission invited the religious communities to study the content and make further recommendations and suggestions. ${ }^{5}$ The several reports of the CRL Rights Commission drew a picture of how religion in South Africa is being commercialised and how people's belief systems are abused in certain religious communities.

In response to the aforementioned reports of the CRL Rights Commission, the South African Council for Religious Rights and Freedoms, and Freedom of Religion South Africa (SACRRF/FORSA) submitted a document, entitled "Comments on the CRL Rights Commission's Report on the 'Commercialisation' of Religion" (28 February 2017). ${ }^{6}$ SACRRF/FORSA requested that their constituencies comment

1 Professor in Ecclesiology, Stellenbosch University.

2 Commission for the Promotion and Protection of the Rights of Cultural, Religious and Linguistic Communities. "Preliminary Report of the Hearings on Commercialisation of Religion and Abuse of People's Belief Systems", 25 October 2016. Online at: https://forsa. org.za/document-library

3 Commission for the Promotion and Protection of the Rights of Cultural, Religious and Linguistic Communities. "Report of the Hearings on Commercialisation of Religion and Abuse of People's Belief System", 26 October 2016. Online at: https://forsa.org.za/ document-library

4 CRL Rights Commission. "Report of the Hearings on Commercialisation of Religion and Abuse of People's Beliefs", June 2017. Online at: https://www.gov.za/documents/reporthearings-commercialisation-religion-and-abuse-peoples-belief-systems-24-apr-2017

5 CRL Rights Commission, Final Report, 27.

6 South African Council for Religious Rights and Freedoms/Freedom of Religion South Africa, "Comments on the CRL Rights Commission's Report on the 'Commercialisation' of Religion", 28 February 2017. 
on the aforementioned document. On behalf of SACRRF, the organisation's chair, Pieter Coertzen, submitted the "Response by the Council for the Protection and Promotion of Religious Rights and Freedoms to the CRL Rights Commission Report on the 'Commercialisation' of Religion and Abuse of People's Belief Systems" (SACRRF Response). The SACRRF Response indicated that the main proposals in the CRL Rights Commission Preliminary Report were unconstitutional, as they amounted to state regulation and state control of religion. ${ }^{7}$ The presumption of SACRRF was that state regulation and state control of religion would violate the right to freedom of religion as guaranteed in Section 15 of the Constitution of the Republic of South Africa, $1996 .{ }^{8}$

Religious organisations, such as SACRRF and FORSA, opposed the proposed regulation of religion. FORSA represents the views of over five million South Africans and SACRRF represents more than 26 million practising religious believers. ${ }^{9}$ SACRRF drafted a "Code of Conduct for Religions in South Africa" as response to the recommendation of Committee of Cooperative Governance and Traditional Affairs (COGTA) on the proposal of the CRL Rights Commission to regulate religion in South Africa. ${ }^{10}$ FORSA supports the Code of Conduct. The duties and responsibilities of religious bodies and religious practitioners are delimited in the Code of Conduct.

The religious institutions and practitioners who signed the Code of Conduct would be encouraged, but not legally compelled, to voluntarily subscribe. ${ }^{11}$ The adoption of such a Code of Conduct is still under discussion amongst the faith communities in South Africa. This chapter examines the context of the constitutional provision of freedom of religion in South Africa, including both religious freedom and freedom of association as constitutional rights. Attention will, therefore, be given to the doctrine of the separation of powers, religious freedom and freedom of association as constitutional rights, problems identified by the CRL Rights Commission, proposed regulatory structure and the registration and licensing of worship centres.

\section{THE DOCTRINE OF THE SEPARATION OF POWERS}

According to public law scholar André Mangu, the doctrine of separation of powers is an "ancient and enduring of element of constitutionalism". ${ }^{12}$ The political

7 SACRRF Response, 2.

8 SACRRF Response, 3.

9 For more information on SACRRF and FORSA, see http://academic.sun.ac.za/theology/ religious-charter/ and https://forsa.org.za

10 SACRRF/FORSA. 2018. "Draft Code of Conduct for Religions in South Africa. Online at: https://forsa.org.za/draft-code-of-conduct-for-religions-in-south-africa

11 SACRRF/FORSA Comments, 5.

12 Mangu AMB. 2009. "Separation of Powers, Independence of the Judiciary, and Good Governance in African Union Member States", Commonwealth Parliamentary Association, 1. Online at: https://www.cpahq.org 
philosopher, John Locke (1632-1704), states in his Second Treatise of Government ${ }^{13}$ that "governments can and should be legally limited in their powers, and their authority and legitimacy on its observing these limitations". ${ }^{14}$ Locke argues that the legislative power should be "put into the hands of divers persons, who duly assembled, have by themselves, or jointly with others, a power to make laws, which when they have done, being separated again, they are themselves subject to the laws they have made".$^{15}$ Locke argues that the functions of government should be separated into legislative, executive and judicial power. ${ }^{16}$ According to Judge Phineas M. Mojapelo, deputy judge president of the Southern Gauteng High Court, legislative authority, executive authority, judicial authority means the following:

(1) Legislative authority - Is the power to make, amend and repeal rules of law.

(2) Executive authority - Is the power to execute and enforce rules of law.

(3) Judicial authority - Is the power; if there is a dispute, to determine what the law is and how it should be applied in the disputes. ${ }^{17}$

A distinction is, therefore, being made between the different branches of government, legislative, executive and judicial. This delineation of powers prevents the branches of government from usurping power from one another.

To prevent the abuse of power, the eighteenth-century French judge, Charles Louis de Secondat, Baron Montesquieu, asserted that there should be a system of separation of power and checks and balances: "To prevent abuse, it is necessary from the very nature of things that power should be a check to power."18 According to Montesquieu, "when the legislative and executive powers are united in the same person, or in the same body of magistrates, there can be no liberty; because many apprehensions may arise, lest the same monarch or senate should enact tyrannical laws, to execute them in a tyrannical manner. Again, there is no liberty, if the judiciary power be not separated from the legislative and executive. Were it joined with the legislative, the life and liberty of the subject would be exposed to arbitrary control; for the judge would then be the legislator. Were it joined to the executive power, the judge might behave with violence and oppression."19

13 Locke J. 2008[1689]. Second Treatise of Government, Bennett J (ed). Online at: http://www. earlymoderntexts.com/assets/pdfs/locke1689a.pdf

14 Stanford Encyclopedia of Philosophy. 2017. "Constitutionalism”, Stanford Encyclopedia of Philosophy. Online at: https://plato.stanford.edu/entries/constitutionalism

15 Locke J. 2010[1690]. Second Treatise of Government, The Project Gutenberg Ebook. Online at: https://www.gutenberg.org/files/7370/7370-h/7370-h.htm

16 Mojapelo PM. 2013. “The doctrine of separation of powers (a South African perspective)", Advocate 26(1):37 46. Online at: https://www.sabar.co.za/law-journals/2013/april/2013april-vol026-no1-pdf

17 Mojapelo, "The doctrine of separation of powers", 37.

18 Montesquieu CL. 2001[1748]. De l'esprit des loix [The spirit of laws]. Nugent T (transl. [1752]). Ontario: Batoche Books, 172; Mangu, "Separation of Powers", 3.

19 Montesquieu, De l'esprit des loix, 173. 
Montesquieu did not invent the doctrine of the separation of powers, but was inspired by English authors before him, including John Locke. Building on the premises of Montesquieu, South African legal scholar Johan van der Vyver asserts that the separation of powers is composed of the following principles:

(1) The principle of trias polita, requiring a formal distinction between the legislature, executive and judicial branches.

(2) The principle of personnel according to which the same people should not be allowed to serve more than one branch of the government at the same time.

(3) Separation of functions between the three branches to avoid one interfering with or assuming the roles of the other.

(4) The principle of checks and balances that requires that each organ be entrusted with special powers designed to serve as checks on the exercise of functions by the others in order to come to an equilibrium. ${ }^{20}$

Trias politica refers to the separation of state powers. ${ }^{21}$ According to Mangu, the "doctrine of the separation of powers assumes that power corrupts and that the separation of power is essential to liberty and democracy". ${ }^{22}$ The notion of separation of powers will be attended to in this chapter.

\section{RELIGIOUS FREEDOM AND FREEDOM OF ASSOCIATION AS CONSTITUTIONAL RIGHTS}

The South African nation consists of a diversity of cultural, religious and linguistic communities. However, the apartheid policies "have bequeathed a legacy of division and inequality between these communities". ${ }^{23}$ Judge Dennis Davis states categorically that the Constitution of the Republic of South Africa, 1996, "was drafted in response to a history of institutionalized racial oppression and arbitrary and capricious rule". ${ }^{24}$ Furthermore, he states that it was "crafted with an understanding of the important role that the law played during apartheid's long history and the manner in which it privileged a racial minority". ${ }^{25}$ According to political scientist Pieter Labuschagne, "during the period 1910-1993, the South African government

20 Van der Vyver JD. 1987. "Political Power Constraints in the American Constitution”, South African Law Journal 104:177-178.

21 Munzhedzi PH. 2017. “The Role of Separation of Powers in Ensuring Public Accountability in South Africa: Policy Versus Practice", 80. Online at: http://hdl.handle.net/10386/1882

22 Mangu AMB. 1998. "Separation of powers and federalism in African Constitutionalism: The South African case". Unpublished Master of Laws Thesis. University of South Africa, 6.

23 Commission for the Promotion and Protection of the Rights of Cultural, Religious and Linguistic Communities Act No. 19 of 2002.

24 Davis DM. 2015. "Twenty Years of Constitutional Democracy: A Preliminary Reflection", New York Law School Law Review 60:42.

25 Davis, "Twenty Years of Constitutional Democracy", 42. 
was marked predominately by the dominance of a fused executive and legislature in a parliamentary system of government." ${ }^{26}$ According to Pius Langa, chief justice of the Republic of South Africa, "the executive and the legislature were closely linked" during the apartheid dispensation. ${ }^{27}$ The interdependence between the executive and the legislature continued after the adoption of the 1983 Constitution. ${ }^{28}$ No provision was made for an independent body like the Judicial Service Commission, as constituted by the Constitution of the Republic of South Africa, 1996. In the pre-constitutional dispensation in South Africa, the separation of powers between the legislature, the executive and the judiciary was non-existent to say the least.

According to Labuschagne, "one of the guiding constitutional principles of the interim and final Constitutions was the provision for the formal separation of powers." ${ }^{29}$ Principle VI of the 34 Constitution Principles, contained in Schedule 4 of the 1993 Constitution, reads as follows: "There shall be a separation of powers between the Legislature, Executive and Judiciary, with appropriate checks and balances to ensure accountability, responsiveness and openness." 30 These powers are constitutionally limited. The Constitution therefor makes provision that there shall be separation of powers between the legislative power (making new laws), executive power (implementing laws) and judicial power (adjudicating disputes under laws), "with appropriate checks and balances to ensure accountability, responsiveness and openness". ${ }^{31}$

Langa rightly argues that, "when the interim Constitution came into force in 1994, it reversed decades of colonial and apartheid policies of racial fragmentation and marked the beginning of a new legal order in South Africa." 32 One of the principles of the Interim Constitution of the Republic of South Africa is the separation of powers. ${ }^{33}$ These powers are constitutionally limited. The separation of powers doctrine was employed in the Constitution of the Republic of South Africa, 1996. The South African Constitution, therefore, makes provision that there shall be separation of powers between the legislative power (making new laws), executive power (implementing laws) and judicial power (adjudicating disputes under laws), "with appropriate checks and balances to ensure accountability, responsiveness

26 Labuschagne P. 2004. "The doctrine of separation of powers and its application in South Africa", Politeia 23(3):84.

Langa PN. 2006. "The Separation of Powers in the South African Constitution", South African Journal on Human Rights 22:1.

28 Republic of South Africa, Act No. 110 of 1983. Langa, "The Separation of Powers", 4.

"Document 35 - Constitutional principles Schedule 4 of the Interim Constitution of the Republic of South Africa". Online at: https://www.sahistory.org.za/archive/document-35constitutional/. The Interim Constitution was drafted during November 1993 by twentysix political groups gathered at Kempton Park near Johannesburg in Gauteng province. 
and openness". ${ }^{34}$ Judge Mojapelo argues that the Constitution does not only "differentiate three spheres of government inter alia legislative, executive and judiciary function, it vests these functions in different organs of state". ${ }^{35}$

The South African Constitution seeks to promote respect for and protection of, the rights of cultural, religious and linguistic communities, as well as to promote unity in diversity. ${ }^{36}$ The Constitution provides protection for freedom of religion, belief and opinion (Section 15), freedom of association (Section 18), safeguards the limitation of rights (Section 36), guarantees a bill of rights (Section 7) and the rights of cultural, religious and linguistic communities (Section 31). The CRL Rights Commission is one of the Chapter Nine institutions, as per Section 181(1) of the Constitution. The other Chapter Nine institutions are the Public Protector, the South African Human Rights Commission, the Commission for Gender Equality, the Auditor-General and the Electoral Commission. The primary objects of the CRL Rights Commission are to "promote respect for the rights of cultural, religious and linguistic communities" (Section 185(1)(a)).

The South African nation consists of a diversity of cultural, religious and linguistic communities. In order to heal the divisions of the past, provision was made in the 1996 Constitution for the creation of the Commission for the Promotion and Protection of the Rights of Cultural, Religious and Linguistic Communities. The Commission only came into existence, however, with the proclamation of the Promotion and Protection of the Rights of Cultural, Religious and Linguistic Communities Act No. 19 of 2002. The CRL Rights Commission assumed its first term of office in 2004. The main purpose of the Commission is to foster social cohesion through the promotion of respect for the rights of cultural, religious and linguistic communities. ${ }^{37}$ From 2015 to 2016, the CRL Rights Commission investigated numerous complaints concerning "pastors instructing their congregants to eat grass and snakes, to allegedly drink petrol or to part with considerable sums of money in order to be guaranteed a miracle or blessing". ${ }^{38}$ The CRL Rights Commission held hearings across the country in all nine provinces between 3 November 2015 and 23 March 2016. 39

Religious organisations and institutions were served with official summonses delivered by the sheriff of the court to appear before the CRL Rights Commission. ${ }^{40}$ These summonses were met with criticism by religious organisations and institutions, for example, the South African Council of Churches, SACRRF, FORSA

34 Munzhedzi, "The Role of Separation of Powers", 80.

35 Mojapelo, "The doctrine of separation of powers", 40.

36 Constitution of the Republic of South Africa of 1996.

37 Promotion and Protection of the Rights of Cultural, Religious and Linguistic Communities, Act No. 19 of 2002, sec 4b.

38 CRL Rights Commission, Preliminary Report, 3.

39 CRL Rights Commission, Preliminary Report, 8.

40 CRL Rights Commission, Preliminary Report, 12. 
and the Methodist Church, as well as from Rev Dr Vukile Mehana, the National Coordinator of the African National Congress Chaplaincy. The latter stated emphatically that the issuing of summons to a number of faith-based organisations to appear before the CRL Rights Commission was "unfortunate" ${ }^{41}$ According to Mehana, this action of the CRL Rights Commission gave rise to a perception that the government, juxtaposing the provisions in the South African Constitution with regard to freedom of religion, belief and opinion and freedom of association, was attempting to regulate religious practice and expressions of faith. ${ }^{42}$ Mehana argued that this approach of the CRL Rights Commission was divergent to "the letter and spirit of the Commission for the Promotion and Protection of the Rights of Cultural, Religious and Linguistic Communities Act, promulgated in 2002". ${ }^{43}$ Mehana emphasised that the "onus is on the churches to ensure they are properly registered and that their financial affairs are properly handled as far as they are being used for the vulnerable and the poor". ${ }^{44}$ He stated categorically that there were existing regulatory frameworks in the country.

SACRRF pointed out that the process followed by the CRL Rights Commission in its investigation was "fundamentally flawed". ${ }^{45}$ The CRL Rights Committee used a "random sampling method" in order "to select random religious institutions/ organisations". ${ }^{46}$ The latter was summoned as per the provision of the CRL Rights Act, "to appear before the Commission". ${ }^{47}$ The CRL Rights Commission stated in their Final Report that this random sampling ranged from large institutions to small institutions, "from main line or traditional churches to charismatic, Pentecostal, Islamic, Bahai Faith, Judaism, Hinduism, non-Christian religions, African Independent churches and African Traditional Religion". 48 In total, over "85 religious and traditional healers' leaders were interviewed". ${ }^{49}$ Of the 85 "religious/traditional institutions" interviewed, 68 (approximately 80\%) were Christian churches (of which 47, or more than half, were Pentecostal or charismatic churches). Leaders from six other religions were interviewed, along with seven leaders representing "African Traditional Healing and Spirituality". ${ }^{50}$

On 30 January 2018, the Committee of Cooperative Governance and Traditional Affairs (COGTA) met to discuss its own report based on the CRL Rights

41 Mehana V. 2015. "State Regulation of Religion an Anathema of ANC Policy", ANC Today, 23 November, 2.

Mehana, "State Regulation of Religion an Anathema", 1.

Mehana, "State Regulation of Religion an Anathema", 1.

Mehana, "State Regulation of Religion an Anathema", 1. SACRRF Response, 5. Rights of Cultural, Religious and Linguistic Communities, Act No. 19 of 2002. 
Commission's Final Report regarding "the regulation of religion and abuse of people's beliefs". ${ }^{51}$ COGTA took cognisance that there had been dispute about the sampling of the consultation by the CRL Commission from the stakeholders who had attended the hearings held in Parliament. ${ }^{52}$ Furthermore, COGTA acknowledged that the entire religious sector had not been consulted in the CRL investigations. ${ }^{53}$

The Preliminary Report of the CRL Rights Commission unleashed an unprecedented response from faith communities in South Africa. The CRL Rights Commission requested the religious organisations and institutions to respond to the report before 28 February 2017. On 27 February 2017, SACRRF and FORSA submitted a joint response on behalf of various major churches, denominations and faith groups in South Africa on the CRL Rights Commission Preliminary Report in which they critiqued the notion of the "commercialisation" of religion. The CRL Rights Commission's assertion is that "controversial news reports and articles in the media about pastors instructing their congregants to eat grass and snakes, to allegedly drink petrol or to part with considerable sums of money in order to be guaranteed a miracle or blessing" brings the question to the fore "whether religion has become a commercial institution or commodity to enrich a few". ${ }^{54}$ The Commission, furthermore, indicated the following as prima face evidence of commercialisation of religion:

(1) People are expected to part with lots and lots of money before blessings and prayers could be said over them.

(2) Blessed water and oils are sold to congregants at a high marked up price.

(3) Access to the spiritual leader or traditional healer is only guaranteed by payment of a fixed amount of money.

(4) T-shirts, Towels, and Vaseline are sold and to congregants to for good luck.

(5) Banks speed points are used for people to swipe their bank cards during ceremonies. ${ }^{55}$

Hence they compiled a report on the "commercialisation" of religion and abuse of people's belief systems. SACRRF/FORSA disagrees with the characterisation of the problem as one of "commercialisation" of religion. But it is, arguably, rather a case of lack of law enforcement and an attempt to infringe the separation of powers.

51 Committee of Cooperative Governance and Traditional Affairs (COGTA). "Report on CRL Rights Commission Report on Regulation of religion and abuse of people's beliefs", 30 January 2018, 1.

52 COGTA Report, 1.

53 COGTA Report, 1.

54 CRL Rights Commission, Final Report, 4.

55 CRL Rights Commission, Final Report, sec 15.1. 
SACRRF also submitted a Charter of Religious Rights and Freedoms to COGTA in order to indicate that the religious organisations in South Africa had already made an attempt to self-regulate. ${ }^{56}$ The South African Charter of Religious Rights and Freedoms (CRRF) was drafted over a period of several years by a continuation committee of academics, religious scholars, religious leaders, government commissioners and international legal experts, in consultation with all major religions, human rights groups and media bodies in South Africa. The South African Charter of Religious Rights and Freedom (CRRF) was signed at a public ceremony in Johannesburg on 21 October 2010 by a number of religious organisations, After the public signing of the CRRF, a Council for the Protection and Promotion of Religious Rights and Freedoms (SACRRF) was established "to oversee the process of the Charter being formally taken to Parliament". ${ }^{57}$ SACRRF in collaboration with the FORSA presented a joint response to the reports of the CRL Rights Commission regarding the "commercialisation" of religion.

In the Final Report, the CRL Rights Commission retained and confirmed much of what was proposed in the Preliminary Report. The Final Report recommended the regulation of religion in South Africa, including the compulsory registration and licensing of all religious institutions and religious practitioners. This proposal was met with protestation from SACRRF and FORSA. The presumption of these organisations is that the proposed regulation of religion, if implemented, would violate the constitutional rights of freedom of religion, belief and opinion (Section 5) as well as freedom of association (Section18). ${ }^{58}$ Furthermore, the SACRRF and FORSA presupposition is that "the recommendations are not saved by Section 36 of the Constitution, and are thus constitutionally impermissible" and that Section 7 of the Constitution placed a duty on the state to "respect, protect, promote and fulfill the rights in the Bill of Rights", therefore, including "the right to religious freedom (Section 15) and the rights of religious communities (Section 31)" ${ }^{59}$

Section 15 of the South African Constitution "confirms and reinforces the amicable and cooperative relationship between religion and the state" ${ }^{60}$ Thus, SACRRF/ FORSA argued, in their response to the CRL Rights Commission, that in the context of the cooperative model, the right to religious freedom should be "understood to include the right to believe and to manifest those beliefs, and freely to establish and organise religious institutions with independent jurisdiction over doctrine and internal affairs". ${ }^{61}$ SACRRF/FORSA stated categorically that this "does not mean that religious institutions are above the law - like all organs of civil society they

56 For more on the South African Charter of Religious Rights and Freedoms, see http:// academic.sun.ac.za/theology/religious-charter/; See also COGTA Report, 1.

57 South African Council for the Protection and Promotion of Religious Rights and Freedoms. Explanatory Notes on the Charter, 2016, 5.

58 SACRRF/FORSA Comments, 2.

59 SACRRF/FORSA Comments, 5.

60 SACRRF Response, 1.

61 SACRRF Response, 1. 
function within the parameters set by law". ${ }^{62}$ SACRRF/FORSA also stated that the proposed regulation of religion would cause a fundamental shift from the existing cooperative relationship between religion and the state to one of state control of religion by law. ${ }^{63}$

\section{PROBLEMS IDENTIFIED BY THE CRL RIGHTS COMMISSION}

SACRRF/FORSA categorised in their comments the various problems identified by the CRL Rights Commission reports under the following headings: practices that are unusual, but not harmful or unlawful; practices that are potentially harmful, dangerous or unethical; the "commercialisation" of religion; non-compliance with the law; misuse of the visa application systems; flouting of banking rules; avoidance of paying tax to SARS; uncontrolled movement of cash in and out of the country; and property bought with the communities money. ${ }^{64}$

According to SACRRF/FORSA, in the CRL Rights Commission Report, the category "practices that are unusual, but not harmful or unlawful" includes "religious practices like feeding people grass"; deification and hero-worship of church leaders by members of their churches (personality cult); or ministers believing themselves to be "angels from heaven", receiving instructions from God (extremist). ${ }^{65}$ According to SACRRF/FORSA, the CRL Rights Commission laid emphasis in their Final Report on the "bizarre, illogical or irrational behaviour of believers". ${ }^{66}$ SACRRF affirms in the Code of Conduct for Religions in South Africa the right of every person to the private or public, and individual or collective, observance or exercise of their convictions in the lawful and constructive ways allowed by the Constitution should be respected. ${ }^{67}$

According to SACRRF/FORSA, the CRL Rights Commission category of "practices that potentially harmful, dangerous or unethical", includes "subjecting members to practices and rituals that evoke questions of human rights and ethics", "recommending and prescribing untested diagnosis and prognosis in health matters", and "questionable religious practices like ... locking people in the deep freezer, driving over people" ${ }^{68}$ The presumption of SARRF and FORSA is that these practices should be dealt with in terms of the existing civil and criminal law and acts regarding animal protection. ${ }^{69}$ SACRRF states emphatically in the Code of Conduct for Religions the right of every person not to be "coerced, indoctrinated,

62 SACRRF Response, 1.

63 CRL Rights Commission, Final Report, 25-27; SACRRF/FORSA Comments, 2.

64 SACRRF/FORSA Comments, 2.

65 CRL Rights Commission, Final Report, 31; SACRRF/FORSA Comments, 20-23.

66 SACRRF/FORSA Comments, 20.

67 Code of Conduct for Religions in South Africa, art 8. Online at: https://forsa.org.za/draftcode-of-conduct-for-religions-in-south-africa

68 SACRRF/FORSA Comments, 20-24; CRL Rights Commission, Final Report, 20.

69 SACRRF/FORSA Comments, 24-25. 
bullied, harassed, intimidated, manipulated or victimised in any way in relation to religion and belief, to be coerced to act against their beliefs, or to participate in behaviour or perform acts that are inconsistent with their beliefs" ${ }^{\prime 0}$

In addition to practices that are potentially harmful or dangerous, the CRL Rights Commission identified practices that are potentially "unethical", including: "advertisements of religious activities in public spaces, making fantastic and mythical promises, soliciting gifts/offerings/donations in cash or kind", "abuse of media privileges, such as using TV slots as a way to advertise themselves or their faith or holy products and claims of healing powers of a wide range of illnesses and socio-economic challenges" and "advertising products without complying with the ASA legislation". ${ }^{71}$ It is the presumption of SACRRF/FORSA that in instances of false advertising, the matter should be referred to the Advertising Standards Authority (ASA). SACRRF/FORSA also indicated in its comments to the CRL Rights Commission Report that "where promises of miracles are made conditional on payment of money however, it may well fall within the scope of the commercialisation of religion. ${ }^{72}$ SACRRF and FORSA affirm in the Code of Conduct for Religions that religious institutions should "refrain from unlawful, corrupt, manipulative or misleading conduct when soliciting contributions or securing funds from members, external donors or other sources". ${ }^{73}$ With regard to complaints regarding commercialisation of religion in the Report of the CRL Rights Commission, the lack of appropriate leadership, management and control mechanisms and processes, SACRRF affirms in the Code of Conduct that faith communities should put in place appropriate leadership, management and control mechanisms and processes to ensure that the internal operations of these institutions are carried out and resources used in a lawful and responsible manner. ${ }^{74}$

The CRL Rights Commission Report cites various examples of non-compliance with the law, including "advertising products without complying with the ASA legislation; forbidding children to attend school; the assertion and justification of registering as private companies and earning funds as entertainers and not as religious practitioners; refusal to use banking facilities and keeping money collected in safes in the institutions"75 and "the use of personal bank accounts as the institution's account". ${ }^{76}$ The presumption of SACRRF and FORSA is that there are enough existing laws in place to deal with the aforementioned issues. The above examples are nothing else than a breach of the Schools Act, 1996, the Companies Act, 2008, and various tax and banking laws, which should be attended

70 Code of Conduct for Religions, art 6.

71 SACRRF/FORSA Comments, 27-28; CRL Rights Commission, Final Report, 9.

72 SACRRF/FORSA Comments, 26-27; CRL Rights Commission, Final Report.

73 Code of Conduct for Religions, art 17.1

74 Code of Conduct for Religions, art 16.

75 CRL Rights Commission, Final Report, 20.

76 SACRRF/FORSA Comments, 30; CRL Rights Commission, Final Report, 19. 
to by law enforcement and not by overregulating religion. SACRRF/FORSA stated that the solution for non-compliance with the law as identified by the CRL Rights Commission is "the effective enforcement of the existing laws and regulations". ${ }^{77}$

The CRL Rights Commission indicated in their report that some churches are not registered either with the Department of Social Development as either non-profit organisations or with the South African Revenue Service (SARS) as public benefit organisations. According to the CRL Rights Commission, some religious organisations or institutions operate "freely without registration or licensing certificate, while others registered with Department of Social Development do not report annually to the Department as required by law". ${ }^{78}$ It is, however, an open question whether religious organisations and institutions are compelled by law in South Africa to register as non-profit organisations. The CRL Rights Commission indicated, "Some pastors apply for a different type of visa, like a visitor's visa or temporary visa, and yet once inside the country, they demand a permanent visa or residence visa and that some foreign religious leaders misuse the SA visa application processes." 79 This is clearly a case which should be dealt with the Immigration Act, 2002, and not by proposing a new regulatory structure. The CRL Rights Commission further indicated that, "in some cases, money collected from the members is never banked with any commercial bank, in some cases, where banking is happening, the money is banked not into the institution's account but the spiritual leader's account, thereby becoming both the pastor and treasurer." ${ }^{80}$ Lastly, the CRL Rights Commission highlighted in their Final Report the "lack of fiduciary committees such as finance, internal audit and financial management" ${ }^{81}$ This problem could be attended to by enforcement of the Banks Act, 1990, the Income Tax Act, 1962, and the South African Reserve Bank Act, 1989, instead of through state regulation and state control of religion in South Africa.

The CRL Rights Commission alluded to the non-profit status of religions and that "most institutions are registered as NPO, and their annual turnover is way beyond the NPO limit, and yet they do not declare this to SARS". ${ }^{82}$ The CRL Rights Commission further noted that some religious organisations and institutions do not disclose to South Africa Revenue Services (SARS) their annual income and in so doing "avoid paying tax". This, surely, is an issue that should be attended to by law enforcement of the SARS Act and should not be achieved by merely overregulating religion in South Africa. SACRRF states in the Code of Conduct for Religions that, where applicable, faith communities should make full disclosure of taxable income, and make diligent payment of taxes due. The CRL Rights Commission brought to light that, in some cases, no permission is sought from the Reserve Bank by churches

77 SACRRF/FORSA Comments, 32. 
with headquarters outside the boundaries of South Africa before money is taken out of the country. ${ }^{83}$ These allegations should surely be investigated by SARS, SAPS, Department of Social Development and National Treasury. Existing laws, such as the Prevention and Combatting of Corrupt Activities Act, 2004, and the Prevention of Organized Crime Act, 1998, should be enforced.

As concerns properties owned by religious groups, the CRL Rights Commission indicated that in some cases, "the title deeds of these religious properties ends up being inappropriately registered, for example, in the spiritual leader's name." 84 This issue should be dealt with through the enforcement of the Deeds Registries Act of 1937 and not by state regulation of worship centres as portrayed in the proposed amendment the Promotion and Protection of the Rights of Cultural, Religious and Linguistic Communities Act No. 19 of 2002. Regarding the alleged misappropriation of funds, SACRRF and FORSA declared categorically that gifts and contributions should only be used for the purpose for which they were received. Furthermore, that any conflict of interests where appropriate should be declared..$^{85}$ The solution for problems regarding the non-enforcement of the law, as identified by the CRL Rights Commission, is more effective implementation and enforcement of the law by the state, not the overregulating of religion.

A lack of good governance practices regarding good, transparent and accountable administration and governance of religious institution's affairs transpired in the Final Report of the CRL Rights Commission, for example, regarding deliberate organisational and administrative deficiencies. This includes failure to maintain financial records, "lack of commitment to responsible financial management and accounting, refusal to use banking facilities and keeping money collected in safes in the institutions and the use of personal bank accounts as the institution's account." 86 The CRL Rights Commission also indicated the lack of good governance and cited examples, such as "lack of fiduciary committees such as finance, internal audit and financial management" and "lack of good governance structures for example some institutions have no codes of conduct and a lack of oversight structures, lack of leadership succession". ${ }^{87}$

\section{PROPOSED REGULATORY STRUCTURE}

The CRL Rights Commission proposed in their Final Report that the Promotion and Protection of the Rights of Cultural, Religious and Linguistic Communities Act No. 19 of 2002 should be amended so as to compel all religious institutions, by law, to register as a non-profit organisation (NPO), a non-profit company (NPC) or a public benefit organisation (PBO), and additionally, that the new legislation 
will establish a number of statutory regulatory bodies responsible for the issuing and revoking of operating licences to all religious institutions and practitioners, depending on their doctrine, and playing a broad policing role over religious institutions and practitioners. ${ }^{88}$ The CRL Rights Commission proposed that the amended act should establish the criteria and procedures required for religion to qualify and to be recognised as a religion. The CRL grounded their proposal to have all religious practitioners register in the country on the provision of the Promotion and Protection of the Rights of Cultural, Religious and Linguistic Communities Act No. 19 of 2002 that the CRL may "establish and maintain databases of cultural, religious and linguistic community organisations and institutions and experts on these communities" ${ }^{89}$ The premise of the CRL Rights Commission is that the proposed act is in line with the Constitution and the Bill of Rights. ${ }^{90}$

In their Second Report, the CRL Rights Commission identified the requirements for a religion to qualify as a religion such as but not limited to:

(1) Religion must have a Religious Text that has a defined origin or an origin proved so ancient that no one alive can remember the true origin.

(2) The founding documents of each religion should be significantly but do not need to be completely different from any other recognized religion.

(3) The religion should have a significant number of followers that believe in and that adhere to the tenants of the faith.

(4) It should have a set of rules and practices that order the lives of followers in a specific and particular way that benefit the followers. No practice should be allowed if deemed to have a harmful effect on the physical or mental well-being of its followers or if deemed exploitive of those that practice it.

(5) The rules and practices of religion should not exploit society in general for the benefit of the religion and at the expense of the religious freedoms of others. ${ }^{91}$

It seems that the CRL Rights Commission works with the presumption that religion should be in some way enshrined in a written document. For example, it states: "Religion must have a Religious Text" and "The founding documents of each religion should be significantly but do not need to be completely different from any other recognized religion." ${ }^{\prime 92}$ It is, however, important to take cognisance thereof that indigenous religions often have no sacred text, as their religious knowledge has been orally passed down from generation to generation.

88 SACRRF/FORSA Comments, 5.

89 CRL Act; CRL Rights Commission, Final Report, 43; (S.5(1)j).

90 CRL Rights Commission, Final Report, 43.

91 CRL Rights Commission, Second Report, 32-33.

92 CRL Rights Commission, Preliminary Report, 33. 
The CRL Rights Commission should have made provision in their proposed legal framework for unwritten forms of religion. To have written texts is not a defining feature of religion, creed, cult, code or community. Seemingly, the CRL Commission's presumption is that unwritten rules and conventions are less precise than those enshrined in written format. The Code of Conduct for Religions in South Africa drafted by SACRRF states also that the rights of others set out in the Constitution, including the right of every person to believe in accordance with their convictions, and to choose their own faith, worldview or religion should be respected..$^{93}$ SACRRF affirms in the Code of Conduct that faith communities maintain traditions and systems and follow practices in terms of religious, personal, matrimonial and family law, to ensure, as required by the Constitution, that those traditions, systems and practices are deemed to be consistent with the Constitution. Furthermore, SACRRF affirms in the Code of Conduct the rights of every religious institution to develop their ethos in accordance with the rules made by the appropriate authorities and in a way that is equitable, free, voluntary and non-discriminatory, and with due regard to the rights of minorities. The CRL Rights Commission deleted the section regarding the "requirements for a religion to qualify as a religion" in their Final Report.

The CRL Rights Commission proposed that the proposed act should indicate the importance for a religion and any subsidiary bodies or institutions, to register in order to operate in the public space and to collect and utilise funds. ${ }^{94}$ According to the CRL Rights Commission, the lack of a religious peer review mechanism led some people in the religious sector to do whatever they want with no accountability to anyone. The CRL Rights Commission, therefore, proposed in their Final Report that religion in South Africa should be regulated. Amongst others, the proposed act should establish and recognise a peer review committee for each religion; it should define what a peer review committee is, how they are registered, and what their powers and mandate are. ${ }^{95}$ Provision is being made in the proposed amendment of the Promotion and Protection of the Rights of Cultural, Religious and Linguistic Communities Act No. 19 of 2002 for various umbrella and peer review bodies representative of religions, for specific religions and denominations, in order to provide for self-regulation by religious institutions, as well as mechanisms and processes established by law, which include "proposals in respect of accreditation, registration, etc. of religious institutions, worship centres, and so-called religious practitioners" (see Figure 23.1 below). ${ }^{96}$ 


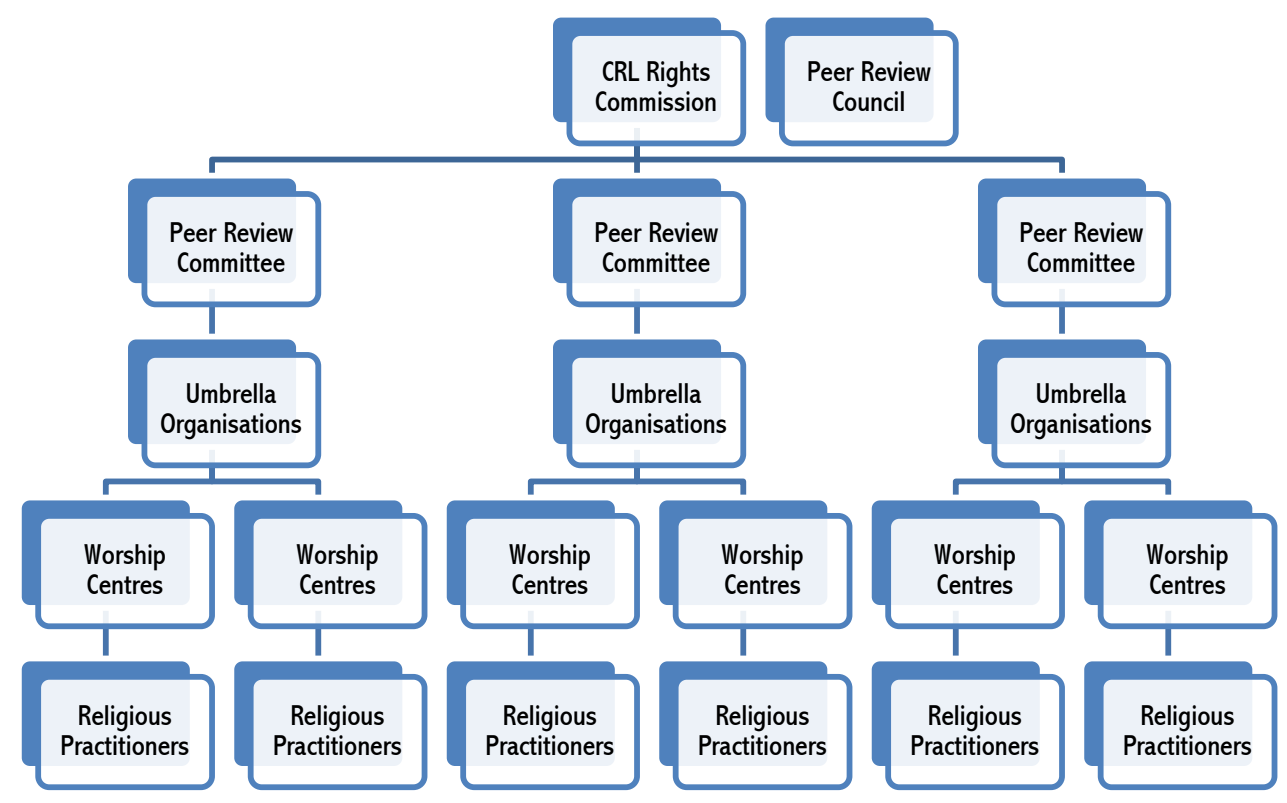

Figure 23.1: Proposed regulatory framework

(Source: CRL Rights Commission Final Report, page 42)

\section{The Peer Review Council}

The CRL Rights Commission proposed that there should be a Peer Review Council, which will consist of peers from each religion that will give permission to operate to individual religious leaders. ${ }^{97}$ The Peer Review Council will consist of one representative per that religion in order to be a multi-faith body. The CRL Rights Commission also proposed that committees of each religion should be constituted, for example, a Christian Peer Review Committee, Muslim Peer Review Committee, Jewish Peer Review Committee, and similarly for other religions. The Commission tried to make provision for the constitution of two bodies, a multi-faith body, namely the Peer Review Council, and religion-specific committees, namely the Peer Review Committees. The Commission indicated, furthermore, that the chairperson of the Peer Review Committee will be a member of the Peer Review Council. ${ }^{98}$ SACRRF/FORSA deem the proposal of the CRL Rights Commission that one person, for example the chairperson of the Christian Peer Review Committee, would represent their religion on the multi-faith Peer Review Council as "unworkable" and "inconsistent with the constitutional right to freedom of religion, and freedom of association". ${ }^{99}$ South Africa is a deeply pluralistic country. The great majority of South Africans are Christians, but that Christian majority can be further subdivided in smaller subdivisions such as Protestants, consisting of Adventists,

97 CRL Rights Commission, Second Report, 32.

98 CRL Rights Commission, Second Report, 34.

99 SACRRF/FORSA Comments, 51-53. 
Africa Independent, Anglican, Baptist, Charismatic, Congregational, Lutheran, Methodist/Wesleyan, Orthodox, Pentecostal, Presbyterian, Reformed, et cetera and Catholics. ${ }^{100}$ Other religions include Judaism, Islam, Buddhism, African Traditional Belief et cetera. The pluralisation of the religious field in South Africa, would make it impossible for one person to represent a specific religion on the multi-faith Peer Review Council and to take part in the execution of discipline over the religious practitioners of a specific religion.

The CRL Rights Commission indicated the following as the responsibilities and powers of the Council:

(1) It shall act as an appeal board to mediate in any matter concerning the registration of religion or any disputes that may arise through the different religious committees that cannot be resolved by the specific religious peer review committee. ${ }^{101}$

(2) The Council may refuse to issue a license if the institution's doctrine is deemed potentially harmful, physically and mentally to those who practice it, or if such doctrine is not found in the tenets of the religion and which bring the religion into disrepute. ${ }^{102}$

The CRL Rights Commission proposed furthermore that the Peer Review Council should only issue an operating licence once the religious institutions comply with the requirements stipulated in the Promotion and Protection of the Rights of Cultural, Religious and Linguistic Communities Act No. 19 of $2002 .{ }^{103}$ One of the tasks of the Peer Review Council would be to act as an "appeal board to mediate in any matter concerning the registration of religion, or any disputes that may arise through the different religious committees that cannot be resolved by the specific religious peer review committee". ${ }^{104}$ The CRL Rights Commission also proposed that the Peer Review Council should "act as a mediator between the different religions, with the CRL being the final appeal (before the matter goes to court) on any inter- and intra-religious matters as well as a mediator in matters between the state and the religious sector". ${ }^{105}$

The premise of the CRL Rights Commission was that this regulatory framework would enable communities and individuals to lodge complaints about religious institutions and individual practitioners to the umbrella organisations the institutions or practitioners belong to. The disciplinary procedures would be conducted by the umbrella organisations. Provision is being made in the proposed regulatory framework that the communities or individuals that have complained

100 South Africa Statistics Census. 2001. Primary tables, South Africa Census 1996 and 2001 compared. Pretoria: Statistics South Africa, 25.

101 CRL Rights Commission, Second Report, 34.

102 CRL Rights Commission, Second Report, 34.

103 CRL Rights Commission, Second Report, 33.

104 CRL Rights Commission, Second Report, 34.

105 CRL Rights Commission, Second Report, 35. 
and institutions or practitioners accused can appeal to their Peer Review Committee and then to the Peer Review Council if they are not satisfied with the decisions taken by the Peer Review Committee. ${ }^{106}$ The Peer Review Council will act as a mediator between the different religions, with the CRL Rights Commission, as the juristic person and a constitutional body, being the final appeal before the court on any inter-and intra-religious matters. ${ }^{107}$ The CRL Rights Commission will remain the final arbiter in all matters recommended by the Peer Review Council and Peer Review Committee. "All final decisions regarding appeals will be taken and implemented by the CRL Rights Commission." 108

SACRRF/FORSA deems the concept of a multi-faith Peer Review Council who would be able by law to judge over any particular religious institution or practitioner, and is given the statutory power to decide whether the particular institution's or practitioner's doctrines, beliefs and practices are acceptable in order to obtain a licence, as "unacceptable, unworkable and a violation of religious freedom and freedom of association". ${ }^{109}$ SACRRF/FORSA states categorically that "state regulation and state control of religion is not the appropriate way to combat abuses" as referred to by the CRL Rights Commission. ${ }^{110}$ The presumption of SACRRF/FORSA is that the "existing legal framework is sufficient to address the abuses effectively. They indicated in their response that the activities of religious institutions are already subject to numerous laws, "which just need to be enforced diligently whenever necessary". ${ }^{111}$ In the Code of Conduct for Religions, SACRRF emphasises that the right of every person to change their convictions, beliefs, faith, religion or religious affiliation, or to form a new religious community or religious institution should be respected. ${ }^{112}$

SACRRF argues that the proposal of the CRL Rights Commission is inconsistent with Section 185 of the South African Constitution. ${ }^{113}$ Chapter Nine institutions act in an advisory capacity to Parliament and the Executive, therefore, they do not exercise executive authority. SACRRF argues that Section 185 does not allow for the expansion of, and even the fundamental shift in, the Commission's powers implied by the proposals in their report. SACRRF submitted, therefore, that the "proposals are inconsistent with the separation of powers as guaranteed in the Constitution". ${ }^{114}$

106 CRL Rights Commission, Preliminary Report, 32.

107 CRL Rights Commission, Preliminary Report, 35.

108 SACRRF/FORSA Comments, 48.

109 SACRRF/FORSA Comments, 48.

110 SACRRF Response, 3.

111 SACRRF Response, 4.

112 Code of Conduct for Religions, art 7.

113 SACRRF Response, 6.

114 SACRRF Response, 7-8. 


\section{Peer Review Committee and umbrella organisations}

The CRL Rights Commission indicated in their proposal that the Peer Review Committee should be chaired by a member of the Peer Review Council, which will have powers and functions to issue accreditations to umbrella organisations. ${ }^{115}$ The CRL Rights Commission set as one of the fundamentals that each religious committee should have a disputes resolution mechanism to hear disputes within a specific religion. ${ }^{116}$

The CRL Rights Commission, furthermore, indicated in its report that it will be expected of all religious institutions to be affiliated with an umbrella organisation. The umbrella organisations are also supposed to register and be known to the Peer Review Committee, which reports to the CRL Rights Commission. ${ }^{117}$ The Peer Review Committee will be made up of representatives of all religions. It shall act as an appeal board to mediate in any matter concerning the registration of religion or any disputes that may arise through the different religious committees that cannot be resolved by the specific religious peer review committee. ${ }^{118}$ The Peer Review Committee shall be an advisory body to the CRL Rights Commission. The final decision powers shall lie with the CRL Rights Commission. ${ }^{119}$ The CRL Rights Commission indicated in their proposed regulation that it will be the task of Peer Review Committees to advise the CRL Rights Commission on matters affecting their particular religion to act as the final mediator of disputes within their own religion and to "deal with complaints from ordinary members of society about the umbrella organisations of their religion". ${ }^{120}$ Lastly, "religious leaders who want to appeal against decisions taken by their umbrella organisation can refer the matter to the Peer Review Committee." 121

The CRL Rights Commission, furthermore, indicated in their proposed regulatory framework that each religion should have accredited umbrella organisations, which will be given powers to recommend the licensing of institutions and individual practitioners. These umbrella organisation will also have the right to apply to the Peer Review Council for the withdrawal of licences of institutions and religious practitioners. ${ }^{122}$ Communities and individuals will be able to lodge complaints about religious institutions and practitioners to the umbrella organisations to which they belong they belong, who will then conduct the disciplinary procedures. ${ }^{123}$ The umbrella organisations will essentially play a broad policing role over religious

115 CRL Rights Commission, Second Report, 32.

116 CRL Rights Commission, Second Report, 32.

117 SACRRF Response, 15.

118 CRL Rights Commission, Preliminary Report, 32.

119 CRL Rights Commission, Final Report, 47; SACRRF Response, 14.

120 CRL Rights Commission, Final Report, 47; SACRRF Response, 14.

121 CRL Rights Commission, Final Report, 47; SACRRF Response, 14.

122 CRL Rights Commission, Second Report, 32.

123 CRL Rights Commission, Second Report, 32; SACRRF/FORSA Comments. 
institutions and practitioners. Umbrella organisations will have the power and responsibility to recommend the issuing or revoking of licences to the Peer Review depending Council, who will make the ultimate decision on the doctrine of the particular institution or practitioner. ${ }^{124}$

\section{Worship centres and religious practitioners}

The CRL Rights Commission proposed in their Final Report that "all religious institutions, worship centres and religious practitioners should be compelled by law to register with state appointed bodies and comply with state determined requirements". ${ }^{125}$ Furthermore, the CRL Rights Commission stated that a religious practitioner, meaning a person who imparts knowledge of the tenants of the faith to a gathering of worshippers, should by law be required to obtain a licence in order to operate and should be registered. The proposed act would also look at the establishment and registering of "worship centres" (churches, masjids, synagogues, etc.). In order to be eligible to operate as worship centre, it needs to obtain a licence as outlined in the proposed act. ${ }^{126}$ The following is indicated as part of the requirements for obtaining a licence:

(1) ... that the worship center has complied with the regulations of the local government that they operate in.

(2) That it must be a member of a duly registered association registered with the Peer Review Committee.

(3) That it must have a constitution that promotes good governance, ethics, transparency, and accountability.

(4) That all religious leaders in charge of or working in such center permanently or temporarily are duly registered and licensed as per the proposed Act. ${ }^{127}$

The Final Report also suggests that, where "worship centres (churches, masjids, synagogues, etc.)" are operated, additional registration/licensing with the relevant umbrella organisation and Peer Review Committee, is required. ${ }^{128}$ In order to qualify for a licence, the "worship centre must be a member of an umbrella organisation, duly registered with the Peer Review Committee, it must have a constitution that promotes good governance, ethics, transparency and accountability, all religious leaders in charge of, or working in, such centre permanently or temporarily, must be duly registered and licensed by the Peer Review Council."129

124 SACRRF/FORSA Comments, 51.

125 CRL Rights Commission, Final Report, 43.

126 CRL Rights Commission, Preliminary Report, 37.

127 CRL Rights Commission, Preliminary Report, 37.

128 SACRRF/FORSA Comments, 53.

129 SACRRF/FORSA Comments, 51; CRL Rights Commission, Preliminary Report, 37. 
Where the centre occupies a permanent or temporary structure for the primary purpose of religious practices, the centre must supply the following: A compliance certificate from the local council, confirming that all by-laws and ordinances were followed in the establishment of the structure; and the assurance that the "worship centre" has enough congregants to maintain it on a donation basis, or proof that there is a source of income that can maintain it. ${ }^{130}$

It is clear from the above that the proposed compulsory licensing of all religious practitioners and places of worship in South Africa, if implemented, would also violate the constitutional rights of freedom of religion (Section 15), freedom of association (Section 18), as well as Section 185. The proposed legislation would result in a major shift from the cooperative model of religion-state relations in post-apartheid South Africa. Section 30 of the Constitution of the Republic of South Africa, 1996, states categorically that, "Everyone has the right to use the language and to participate in the cultural life of their choice, but no one exercising these rights may do so in a manner inconsistent with any provision of the Bill of Rights." SACRRF acknowledges in the Code of Conduct for Religions the duty of the state to respect, protect, promote and fulfil the constitutional right to freedom of religion and belief, and affirm that they will encourage cooperation between religions and the state in line with the constitutional provisions. ${ }^{131}$

\section{CONCLUSION}

According to COGTA, there has been extensive disagreement about the constitutionality of the recommendations put forward by the CRL Commission. ${ }^{132}$ COGTA, therefore, recommended that "government had to strengthen existing legislation; specifically the Non-Profit Organizations Act No. 71 of 1997, Income Tax Act both of which applied to religious organizations". ${ }^{133}$ Juxtaposing to the elaborated regulatory framework proposed as new legislation by the CRL Rights Commission, COGTA urged the government to push for registration of religious bodies as NPOs and enforce the NPO Act, which required that religious organisations to submit the financial statements and constitutions and changes in their leadership structures. Furthermore, COGTA recommends that the religious sector had to develop a "code of conduct for religious bodies and that had then to be recognized in terms of the law" ${ }^{134}$ In 2018, SACRRF forwarded a draft Code of Conduct to faith communities for their input. The response of the faith communities is still awaited.

With the proposed legislation, the CRL Rights Commission tried to secure the executive function and to adjudicate conflicts between religious institutions and individuals and between state and religious institutions in themselves. As argued

130 SACRRF/FORSA Comments, 51; CRL Rights Commission, Preliminary Report, 37.

131 Code of Conduct for Religions, art 10.

132 COGTA Report, 1.

133 COGTA Report, 1.

134 COGTA Report, 1. 
above, the powers of the Chapter Nine institutions are constitutionally limited. Chapter Nine institutions are not at liberty to change or expunge those limits. The CRL Rights Commission's proposal to regulate religion can be seen as overstretch of its legislative powers and prerogatives as a Chapter Nine institution, under which it is not granted executive power. Nowhere in Section 185 or elsewhere in the Constitution of the Republic of South Africa, 1996, is the CRL Rights Commission "empowered to be a regulatory or enforcing body in respect of religion". ${ }^{135}$ The CRL Rights Commission, therefore, has no right to assume executive powers. SACRRF rightly argues that, "conferring on the CRL Rights Commission the deciding and final authority in respect of religious issues could be deemed as inconsistent with the Constitution." 136 I concur with the SACRRF/FORSA that the "requirement that every religious institution and/or practitioner be compelled, by law, to belong to an umbrella organization, is also a violation of the fundamental right to freedom of association which guarantees an individual the right to choose one's associates, and a group of individuals (or an organization) their rights to choose their associates."137

The regulatory framework as proposed by the CRL Rights Commission is, therefore, in conflict with the foundational basis of principles of constitutionalism, namely the principle of separation of powers. My submission is that the proposed amendment of the Promotion and Protection of the Rights of Cultural, Religious and Linguistic Communities Act No. 19 of 2002 is nothing else than an attempt of the CRL Rights Commission to secure executive authority, meaning the power to execute and enforce rules of law in themselves. The constitutional limitations of the CRL Rights Commission include the scope of authority (authority over the cultural, religious and linguistic communities); the mechanisms used in exercising the relevant power (governing the form and manner of legislation); and civil rights (enshrined in the Bill of Rights). Instead of observing these limitations, the CRL Rights Commission, through the proposed regulation, tried to expunge these limitations. In doing so, the CRL Rights Commission tried to exceed the scope of their legislative competence. The proposed legal framework is, therefore, a violation of the provision in the South African Constitution, regarding religious freedom and the doctrine of separation of powers.

The proposed amendment of the Promotion and Protection of the Rights of Cultural, Religious and Linguistic Communities Act No. 19 of 2002 suggests that the CRL Rights Commission will be the final authority on all religious matters. The main proposals in the Final Report of the CRL Rights Commission amount to state regulation and state control of religion, which would be a violation of the right to religious freedom guaranteed in Section 15 of the Constitution of the Republic of South Africa, 1996, and is, therefore, unconstitutional. Judge Mojapelo rightly argues that "the executive authority is not supposed to enact law or to administer justice".

135 SACRRF Response, 7; Constitution of the Republic of South Africa of 1996, sec 181(2)-(5).

136 SACRRF Response, 7.

137 SACRRF/FORSA Comments, 51. 